\title{
Kinetic Spectrophotometric Determination of Trace Amounts of Sulfide
}

\author{
Mohsen Barzegar, ${ }^{*}$ Ali Jabbari, ${ }^{\dagger}$ and Majid Esmaeilit \\ Department of Food Science and Technologv, Tarbiat Modarres University, P.O. Bor 14115-336, Tehran, Iran \\ -Department of Chemistry, K. N. Toosi Lniversity, Tehran, Iran \\ -Department of Chemistry, Razi Lniversity, Kermanshah 67149, Iran \\ Received February 25, 2003
}

\begin{abstract}
A method for the determination of trace amount of sulfide based on the addition reaction of sulfide with methyl green at $\mathrm{pH} 7.5$ and $25^{\circ} \mathrm{C}$ is described. The reaction is monitored spectrophotometrically by measuring the decrease in absorbance of the dy'estuff at $637 \mathrm{~nm}$ by the initial rate and fixed time method. The calibration graph is linear in the range $30-1200 \mathrm{ppb}$. The theoretical limit of detection was $0.014 \mathrm{ppm}$. Seven replicate analysis of a sample solution containing $0.70 \mathrm{ppm}$ sulfide gave a relative standard deviation of $1.5 \%$. The interfering effects of various ions on sulfide determination have been reported and procedures for removal of interference have been described. The proposed method was applied successfilly to the determination of sulfide in tap and wastewater samples.
\end{abstract}

Key Words : Sulfide, Kinetic spectrophotometric, Methyl green. Slope method, Fixed time method

\section{Introduction}

Hydrogen sulfide is a by-product of many industrial processes and it is also formed during putrefaction of proteinaceous substances containing sulfur. ${ }^{l}$ This hazardous gas can also be produced when elementary sulfur or sulfur containing compounds react with organic material at high temperature. The monitoring of sulfide is required in a variety of environmental and industrial applications. including odor assessments. health and safety investigations. routine industrial/off-line monitoring programs, and regulatory compliance issues as a consequence of the toxicity of any liberated hy'drogen sulfide. ${ }^{2}$ There are limits on the total level of sulfide permitted in waste discharges in most countries because of toxicity and capacity to remove dissolved oxygen. ${ }^{3 .+}$ Sulfide in $\mathrm{H}_{2} \mathrm{~S}$ form is toxic to fish and other aquatic organisms ${ }^{5}$ and can be responsible of the decrease in wastewater treatment plants efficiency. Hence. its concentration needs to be controlled. especially in water and wastewater.

Sulfide can be determined in different media. using various techniques. These include titrimetric. ${ }^{6}$ flow-injection analysis ${ }^{7.8}$ amperometric ${ }^{5}$ polarographic. ${ }^{16}$ ion chromatography. HPLC ${ }^{13} \mathrm{GC}^{14}$ and spectrophotometric. ${ }^{15.16}$

Although chromatographic methods have low detection limits. they generally require complex and time-consuming sample preparation procedures. are expensive and are not easily adapted to field analy'sis.

Kinetic methods have been widely used in catalytic and non catalytic determination of various chemical species. ${ }^{17-19}$ The different techniques and procedures associated with this type of method have been reviewed ${ }^{2021}$ Kinetic methods for the determinations of micro amounts of sulfide have been described ${ }^{2-2+}$ However. most of these methods suffer from

\footnotetext{
${ }^{*}$ Corresponding author. Fax: +98 214196524 ; e-mail: mbbat
} modares.ac.ir interfering effects of other sulfur anions or low linear dynamic range and some are time-consuming. Thus. simple. rapid. and selective methods are still required.

In this work we report a kinetic spectrophotometric method based on the addition reaction of sulfide with methyl green at $\mathrm{pH} 7.5$ for the determination of sulfide in trace levels. Application of the developed method was evaluated by measuring the sulfide content in tap water and wastewater samples.

\section{Experimental Section}

Materials. All reagents were analytical-reagent grade (from Merck or Aldrich) and used without further purification. Doubly distilled water was used throughout the experiment.

Sulfide stock solution ( $1000 \mathrm{ppm})$ was prepared daily by dissolving $0.7506 \mathrm{~g}$ of $\mathrm{Na}_{2} \mathrm{~S}^{2} 9 \mathrm{H}_{2} \mathrm{O}$ (Merck) in water and diluting to $100 \mathrm{~mL}$. This solution can be standardized iodometrically ${ }^{25}$ or potentiometrically ${ }^{26}$ Standards of working solution were made by appropriate dilution daily as required.

Methly green stock solution (Merck. $1.0 \times 10^{-4} \mathrm{M}$ ) was prepared by dissolving $0.0608 \mathrm{~g}$ of methyl green in water and diluting to $100 \mathrm{~mL}$ in a calibrated volumetric flask. Ten $\mathrm{mL}$ of this solution was diluted to $100 \mathrm{~mL}$ and used as a working solution. Phosphate buffer ( $\mathrm{pH} 7.5$ ) was prepared by mixing a suitable amount of $\mathrm{K}_{2} \mathrm{HPO}_{4}(0.0 \mathrm{l} \mathrm{M})$ and $\mathrm{KH}_{\unlhd} \mathrm{PO}_{4}(0.01 \mathrm{M})$ in a $100 \mathrm{~mL}$ volumetric flask.

Apparatus. The absorption spectra were recorded on a Cecil 9000 UV-Vis double beam spectrophotometer (Cecil Instruments Limited. England) and measurements at a fixed wavelength were made with a 662 Metrohm probe type photometer. The Metrolum photometer was connected to a computer using a 12 Bit A/D card (model 1201. Bitpardaz Co.. Tehran. Iran) and the appropriate software was written in Quik Basic in our laboratory. The changes in absorbance 
with time were displayed on the screen. A magnetic stirrer (model ZMS 74, ZAG CHIMIE Co., Tehran, Iran) was used for mixing of reagents and $\mathrm{pH}$ was adjusted using a 691 Metrohın $\mathrm{pH}$ meter. The temperature was controlled by a thermostated water bath (model HAAKE DI). The temperature was maintained constant in the reaction cell by circulating water at appropriate temperature around the cell of the photometer during the experiment. The addition of sulfide solution to reaction cell was carried out using Hamilton syringes with different volumes.

Procedure. Two separate procedures were adopted. Both of two procedures were performed by direct data collection by computer. The first method was based on the conventional fixed time method and the second on the slope method. In the cell of reaction, $2.0 \mathrm{~mL}\left(1.0 \times 10^{-5} \mathrm{M}\right)$ of methyl green solution was added to $1.0 \mathrm{~mL}$ of $0.01 \mathrm{M}$ phosphate buffer ( $\mathrm{pH} 7.5)$ and diluted to $7.0 \mathrm{~mL}$ by addition of appropriate amounts of water. Probe was inserted in the cell and the deviation in absorbance of blank was saved in computer. A magnetic stirrer was used to mix the reagents. Then $50-100 \mu \mathrm{L}$ of sulfide solution was added to initiate the reaction and the absorbance versus time data were collected by the computer. With a fixed time method, absorbance changes were measured between $0-15 \mathrm{~s}$ after start of the reaction. In the slope method, the slope of the plot of absorbance versus time was found during the first $10 \mathrm{~s}$ after starting the reaction.

\section{Results and Diseussion}

Methyl green is an acid-base indicator and exists in two

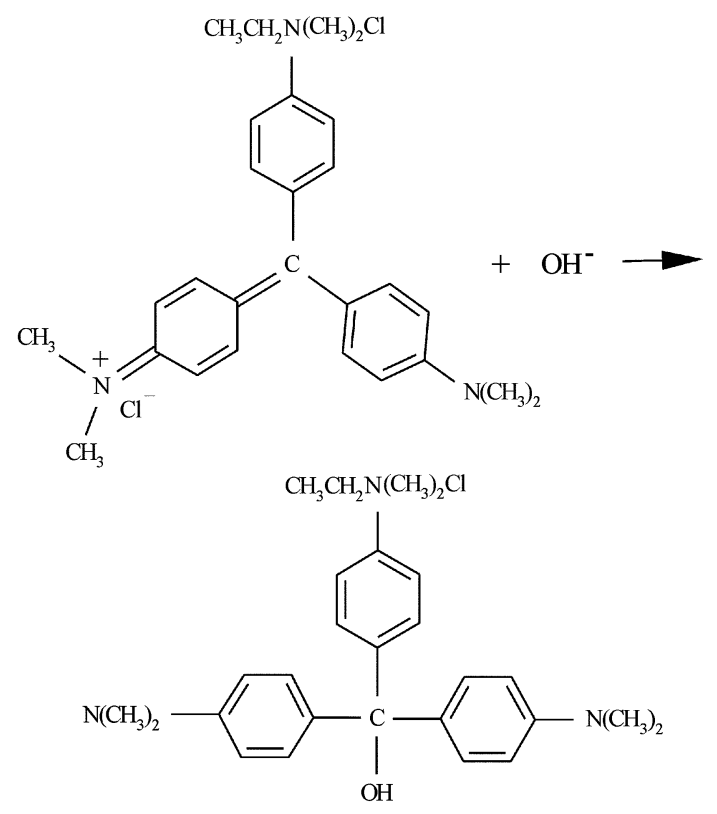

forms, $\mathrm{R}^{\prime}$ and $\mathrm{ROH}$, depending on the $\mathrm{pH}$ of solution. ${ }^{-7}$ Addition of sulfide to methyl green occurs at $\mathrm{pH} 6.0-8.0$ (at $25^{\circ} \mathrm{C}$ ). This causes a relatively rapid change of the color of solution from blue to colorless even in the presence of small

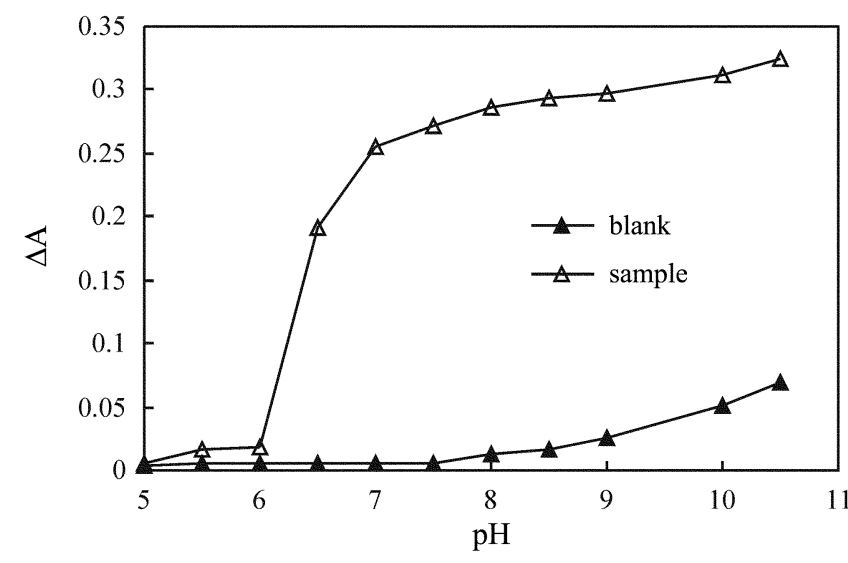

Figure I. Folect of $\mathrm{pH}$ on the reaction rate. Conditions: [methy] green] $3.3 \times 10^{-6} \mathrm{M}: 0.50 \mathrm{ppm}$ sullide: $\mathrm{I}=25^{\circ} \mathrm{C}$ : lixed time $15 \mathrm{~s}$.

amounts of sulfide (ppb).

Effect of Variables. The effect of $\mathrm{pH}$, concentration of methyl green, ionic strength and temperature on the additional reaction of sulfide with methyl green was studied by the fixed time and slope method.

The decrease of absorbance of methyl green in the presence and absence of sulfide was measured in the $\mathrm{pH}$ range 5.010.0 using phosphate buffer. $\mathrm{HCl}$, or $\mathrm{NaOH}$ solutions for $\mathrm{pH}$ adjustments. The effect of $\mathrm{pH}$ on the rate of reaction of $3.3 \times 10^{-6} \mathrm{M}$ methyl green in the presence of $0.50 \mathrm{ppm}$ sulfide is shown in Figure 1. As it is seen, the difference between blank and sample reaction rate was increased with increasing $\mathrm{pH}$ from 5.0 through 7.5 . So $\mathrm{pH} 7.5$ was used as optimum $\mathrm{pH}$ because of maximum difference between the rate of blank and sample reaction. Above $\mathrm{pH} 7.5$ the rate of blank reaction is increased owing to the formation of $\mathrm{ROH}$.

The influence of methyl green concentration on the reaction rate at $\mathrm{pH} 7.5$ was also investigated and the results are shown in Figure 2. It is seen that there was an increase in the reaction rate when the concentration of methyl green was varied from $0.8 \times 10^{-6}-3.3 \times 10^{-6} \mathrm{M}$ while at higher concentration of methyl green no considerable change in the reaction rate was observed. Thus the optimum concentration of methyl green was chosen as $3.3 \times 10^{-6} \mathrm{M}$.

The effect of ionic strength on the rate of reaction rate was studied. The ionic strength was varied from $0.01-0.10 \mathrm{M}$ using $\mathrm{NaNO}_{3}$ solution. The results showed that this factor had no effect on the reaction rate up to $0.04 \mathrm{M}$. A further increase of ionic strength caused a decrease in the reaction rate.

The effect of temperature on the reaction rate was investigated in the range $5-50{ }^{\circ} \mathrm{C}$. Figure 3 shows that the reaction rate of sulfide increased with increasing temperature while the blank had no considerable change up to $25^{\circ} \mathrm{C}$. Temperature of $25^{\circ} \mathrm{C}$ was selected as the best working temperature, since at this temperature the differences between blank and sample reaction rate is large and it is suitable for subsequent uses. Optimum conditions were chosen as follows: $\mathrm{pH} 7.5$ : [methyl green] $-3.3 \times 10^{-6} \mathrm{M}$; temperature $25^{\circ} \mathrm{C}$; measuring time 15.0 and $10.0 \mathrm{~s}$ for fixed time and slope method, 


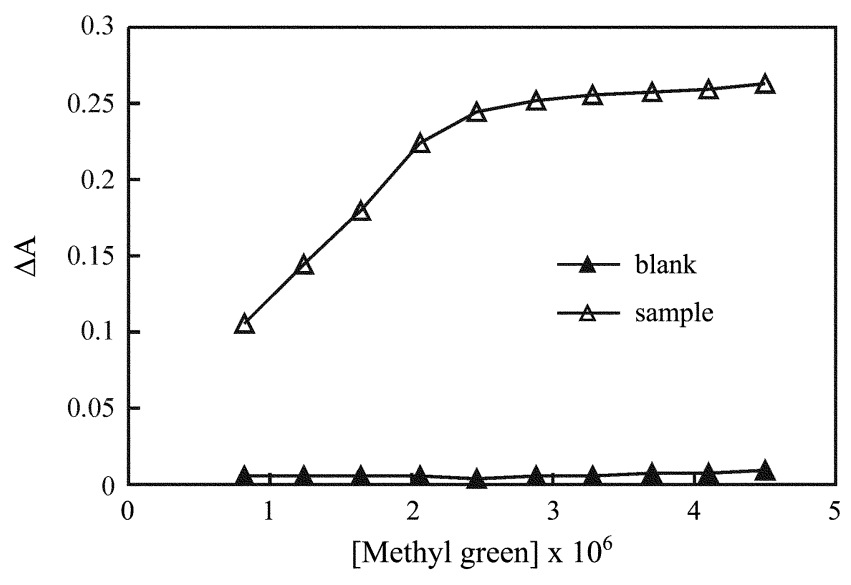

Figure 2. Filect of methyl green concentration on the reaction rate. Conditions: pl $7.5 ; 0.50 \mathrm{ppm}$ sullide: $1=25^{\circ} \mathrm{C}$ : fixed time $15 \mathrm{~s}$.

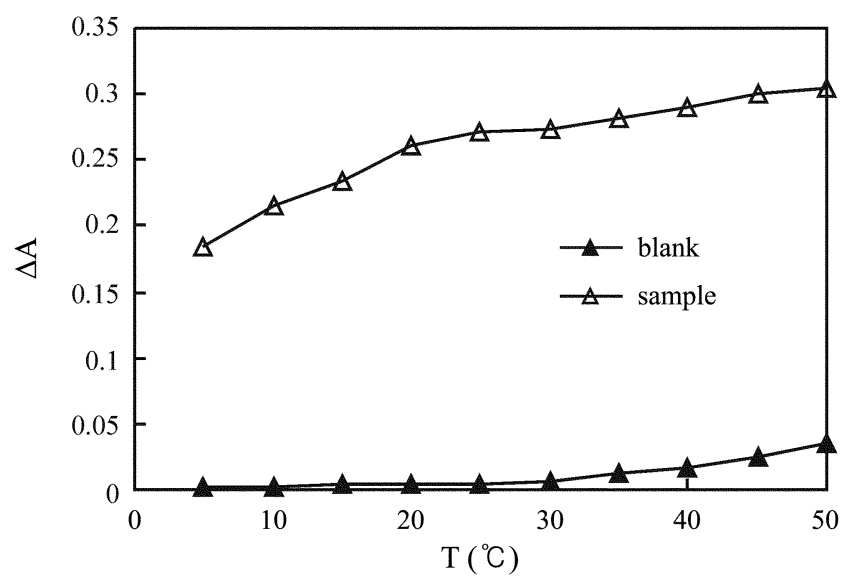

Figure 3. Inlluence of temperature on the rate of reaction. Condilions: pll $7.5: 0.50 \mathrm{ppm}$ sulfide: [melhyl green] $=3.3 \times 10^{-6}$ $\mathrm{M}$ : fixed time $15 \mathrm{~s}$.

respectively; $\lambda_{\text {nux }}-637 \mathrm{~nm}$.

Calibration Graph, Precision, and Limit of Detection. Under optimum conditions two linear calibration graphs were prepared (Table 1). Seven replicate analysis of a sample solution containing $0.70 \mathrm{ppm}$ sulfide gave a relative standard deviation of $1.5 \%$. The theoretical limit of detections ${ }^{28}$ were 0.014 and $0.017 \mathrm{ppm}$ for fixed time and slope method, respectively according to $Y_{D L}-Y_{B}+E_{B}$ where $Y_{D L}, Y_{B}$, and $E_{12}$ are signal of detection limit. blank signal and noise of the blank, respectively. As the results imply, the fixed time method and slope methods are comparable with each other.

Effect of Foreign Ions. The interference due to several cations and anions was studied in detail. Different amounts of ionic species were added to the sulfide solution. The concentration of sulfide was $0.50 \mathrm{ppm}$ in solution. The tolerance limit was taken, as the amount required causing $+4 \%$ error in the sulfide recovery. The results are presented in the Table 2.

Removal of Interference's. The most of the cations that interfere in sulfide determination form insoluble metal sulfides. Interference effects of these cations were removed
Table 1. Analytical characteristics of the elaborated method

\begin{tabular}{|c|c|c|}
\hline & $\begin{array}{l}\text { Culibration graph } \\
\text { (fixed time method) }\end{array}$ & $\begin{array}{l}\text { Calibration graph] } \\
\text { (slope method) }\end{array}$ \\
\hline Fiquation & $\begin{array}{l}\Delta \mathrm{A} \quad 1.03 \times 10^{-3} \\
+5.43 \times 10^{-1} \mathrm{C}^{a}\end{array}$ & $\begin{array}{rr}\mathrm{dA} / \mathrm{dl} & -4.81 \times 10^{-6} \\
\cdot & 4.93 \times 10^{-4} \mathrm{C}^{\mathrm{ct}}\end{array}$ \\
\hline l. inear range (pph) & $30-1200$ & $40-1200$ \\
\hline $\mathrm{N}^{-h}$ & 16 & 16 \\
\hline Correlation coell. & 0.9987 & 0.9985 \\
\hline $\mathrm{RSI} \%$ & $0.9-2.3^{c}$ & $0.85-2.2^{c}$ \\
\hline 1.01$)\left(p_{p h}\right)$ & 14.0 & 17.0 \\
\hline
\end{tabular}

"Concentration of sulficle in ppb. "Nurnber of calibration points. "For sulfide concentration of $50-1100 \mathrm{ppb}$.

Table 2. I:Ifect of foreign ions on the reaction rate of $0.50 \mathrm{ppm}$ sullide

\begin{tabular}{|c|c|}
\hline lioreign ion & $\begin{array}{l}\text { Iolerance limit } \\
\qquad(\mathrm{ppm})\end{array}$ \\
\hline $\mathrm{Na}^{-} \cdot \mathrm{K}^{-} \cdot \mathrm{I}^{-} \cdot \mathrm{Cs}^{-} \cdot \mathrm{Cl}^{-} \cdot \mathrm{F}^{-} \cdot \mathrm{I}^{-} \cdot \mathrm{Br} \mathrm{r}^{-}$ & $100 \%$ \\
\hline $\begin{array}{c}\mathrm{HCO}_{3}^{-}, \mathrm{S}_{2} \mathrm{O}_{3}{ }^{2-}, \mathrm{SO}_{4}^{2-}, \mathrm{CH}_{3} \mathrm{COO}^{-} . \mathrm{NO}_{3}^{-} . \mathrm{SCN}^{-} \\
\mathrm{NO}_{2}^{-} \mathrm{W} \text { (VI) I. a (III) }\end{array}$ & $8000^{t t}$ \\
\hline 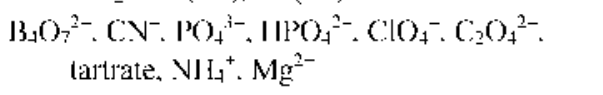 & 500 \\
\hline FIDIA. Mo(VI) Cr (VI) & 200 \\
\hline Formaldehyde & 100 \\
\hline $\mathrm{Si}^{2+} \cdot \mathrm{Ni}^{2-} \cdot \mathrm{Fe}^{2+} \cdot / \mathrm{J}(\mathrm{IV})$ & 50 \\
\hline $\mathrm{Al}$ & 10 \\
\hline $\mathrm{Cu}^{2-}$ & 5 \\
\hline $\mathrm{SO}_{3}^{2-} \cdot 1 \mathrm{OO}_{3}^{-}$ & Interlèred \\
\hline $\mathrm{I}^{2} \mathrm{~b}^{2+} \cdot 1 \mathrm{lg}^{2-}, \mathrm{Ag}^{+}, 1 \mathrm{lg}^{+}$ & Interlered \\
\hline
\end{tabular}

by the addition of iodide or hydroxide ions and filtering the solution prior to each measurement. These cations also can be successfully removed from the solution by passing it from a column containing a strongly acidic cation exchanger of $\mathrm{H}^{+}$form (Merck). Among the anions, sulfite and iodate interfere. Sulfite interference can be eliminated by the addition of $0.4 \mathrm{~mL}$ of $0.05 \%$ formaldehyde to $7.0 \mathrm{~mL}$ of test solution prior to each measurement. The interfering effect of iodate was removed by the addition of $1.0 \mathrm{~mL} 500 \mathrm{ppm}$ iodide to $7.0 \mathrm{~mL}$ of test solution prior to each measurement. Since cyanide did not interfere, the interfering effect of silver was removed by the addition of cyanide to form stable silver cyanide complex and thus preventing silver sulfide formation. In addition, the interfering effects of $\mathrm{Pb}^{2}, \mathrm{Cu}^{2}$ and $\mathrm{Hg}, \mathrm{Hg}^{21}$ were removed by the addition of hydroxide ( 100 $\mathrm{ppm}$ ) and iodide (100 ppm), respectively, to form precipitates and thus preventing metal sulfide precipitation. The results are summarized in Table 3.

Application. To confirm the usefulness of the suggested method, sulfides were determined in tap water and wastewater samples. After proper dilution of the sample, the wastewater sample was first treated with $\mathrm{NaOH}$ and filtered. The $\mathrm{pH}$ of filtrate was then adjusted to about 7.5 with $\mathrm{HCl}$. Results are given in Table 4. The results show that the method is suitable for the analysis of real samples. 
Table 3. The accuracy after removal of interfering ion $(0.50 \mathrm{ppm}$ sulfíde)

\begin{tabular}{lccc}
\hline $\begin{array}{l}\text { Intertering } \\
\text { ion }\end{array}$ & Masking agent & $\begin{array}{c}\text { Sulfide found } \\
(\mathrm{ppm})\end{array}$ & $\begin{array}{c}\text { RSD } 0 \\
(n=3)\end{array}$ \\
\hline $\mathrm{SO}^{2-}(2)^{4}$ & Formaldehyde $\left(0.003^{\circ} \cdot 0\right)^{\alpha}$ & 0.486 & 1.20 \\
$\mathrm{IO}_{5}^{-}(5)$ & $\mathrm{I}^{-}(100)$ & 0.475 & 1.10 \\
$\mathrm{Ag}^{-}(10)$ & $\mathrm{CN}^{-}(50)$ & 0.485 & 1.60 \\
$\mathrm{~Pb}^{2^{-}}(10)$ & $\mathrm{OH}^{-}(100)$ & 0.502 & 0.95 \\
$\mathrm{Hg}^{-}(10)$ & $\mathrm{I}^{-}(100)$ & 0.493 & 1.14 \\
$\mathrm{Cu}^{2-}(10)$ & $\mathrm{OH}^{-}(100)$ & 0.495 & 2.10 \\
$\mathrm{Hg}^{2-}(10)$ & $\mathrm{I}^{-}(100)$ & 0.490 & 1.60 \\
\hline
\end{tabular}

"The term in parenthesis are concentration of interfering or masking agents in ppm except for formaldelyde.

Table 4. Analysis of real samples by developed method ${ }^{x}$

\begin{tabular}{lccc}
\hline \multirow{2}{*}{ Sample } & \multicolumn{2}{c}{ Proposed method } & \multirow{2}{*}{ Standard method $^{b}$} \\
\cline { 2 - 3 } & Fixed time & Slope & \\
\hline Tap water & 18.73 & 18.26 & 18.53 \\
Wastewater & 31.60 & 32.64 & 32.02 \\
\hline
\end{tabular}

"Five replicate determinations. ${ }^{6}$ Standard method [25. 28].

\section{Conclusions}

This work describes a relatively inexpensive. rapid. simple. and sensitive method for the determination of trace amounts of sulfide based on the addition reaction with methyl green. The analytical system is simple and needs minimum maintenance and most of ions do not interfere.

\section{References}

1. Puacz. W: Szahun. W: Linke. K. Anahyst 1995, 120.939

2. Patnaik. P. A. Comprehensive Guide to the Hazardous Properties of Chentical Substances. 2nd ed.: Wiley: New York. 1999.
3. Ebdon. L. Hill. S. J; Jameel. M: Cons. W. T.: Stockwell, P. B Andlyst 1997. 122. 689 .

4. Kirk. R. E.: Othmer. D. F. Encyclopedia of Chemical Techologn. 3nd ed.: Wiley: New York. 1981: vol. 17

5. Eaton. A. D.: Clesceri, L. S.: Greenberg. A. E. Standord Methods for the Exantination of Water and Wastewater. 19nd ed.; American Public Health Association: Washington, 1995.

6. Liu. C. H.: Shen. S. Anal. Chem. 1964. 36. 1652

7. Lambert. T. L.: Manzo. D. T. And. Chim. Acta 1969. 18.185

8. Roman Ceba. M.: Vinagre Tava. F.: Munoz Leyva. T. A. Anatyst 1982. 107,781 .

9. Kurzawa. J. Anal Chint Acta 1985. 173. 343.

10. Canterford, D. R. Anal. Chem. 1975, 47.88.

11. Casella. I. G.; Guascito. M. R.: Desimoni. E. Anal Chim. Acto 2000. 409.27

12. Steinmanin. P.: Shotyk. W. J. Chrontatogr A 1995. 706.287.

13. Tang. D.: Santschi. P. D. J. Chrontatogr: A 20M0. 883. 305.

14. Radford-Knoery. J: Cutter, G. A. Andl. Chem. 1993, 65.976.

15. Wood, C. F.: Marr. I. L. Anatyst 1988, 113. 1635.

16. Koh, T.: Miura. Y.: Yamamuro. N.: Takaki, T. Anabst $1990,115$. 1133.

17. Barzegar. M.: Rahmani. A.: Tabbari. A.: Mousavi. M. F. Pharntazie 2003. 58. 114

18. Jabbari, A.; Barzegar. M.: Rahmani, A.; Mousavi. M. F. Indian J. Chem. 2002, 33. 2303.

19. Barzegar, M.; Mousavi. M. F.; Nemati, A. Microchem. d. 2000. 65. 159.

20. Bendito. D. P.: Silva. M. Kinetic Methods in Anatytical Chentistr: Horwood: Chichesters. 1988.

21. Yatsimirski, K. B. Kinetic Methods of Anahsis Pergamon: Oxford. 1966

22. Han. K.: Koch. W. F. Anal Chem. 1987. 59. 1016

23. Lei. W.: Dasgupta. P. K. Anal. Chim Acta 1989. 226. 165.

24. Ensafi. A. A. Anal Lett. 1992. 25. 1525.

25. Jeffery. G. H.: Bassett. T.: Mendhann. J.: Denney. R. C. Togel's Textbok of Outmitative Chemical Anatysis. 5nd ed: John Wiley \& Sons: New York, 1989: p 398.

26. Hseu. T. M.; Rechnitz, G. A. And. Chem. 1968, 40. 1055.

27. Cheng. K. L.: Uendo. K.: Imamura. T. Handbook of Organic Analvical Reagents. CRC Press Inc: 1982: $\mathrm{p} 462$.

28. Miller. I. N.: Miller. I. C. Statistics and Chentontetrics for Analutical Chemistry; Pearson Education Limited: England. 2000. 